\title{
Measuring Green Marketing Strategy for Resort Spa in Bali
}

\author{
by

\section{Rr. Astrid Adiyanti Prawitasari (1) Ida Bagus Raka Suardana ${ }^{(2)}$}

\author{
Universitas Pendidikan Nasional ${ }^{(1)}$ \\ Universitas Pendidikan Nasional ${ }^{(2)}$ \\ astridadiyanti@gmail.com ${ }^{(1)}$ \\ ajikraka@yahoo.com ${ }^{(2)}$
}

\begin{abstract}
According to the expert, the spa industry is still growing and can be used as green washing. Therefore, it is important for the spa industry to also poised to offer adequate solutions and lead the way on how we can achieve sustainable well being within protecting the world. Fairmont Sanur The Spa, as the winner of Best Leading Spa Resort 2017/2018 by Bali Tourism Award realize the increase interest of customer for 'something green' also impact their business. The customers sincere awareness about environment make them realize that they might have to run things differently from now on, starting with checking their green marketing strategy due to up until now they only focus on the regular marketing. The purpose of this study is to develop a green marketing strategy for the green spa industry which is exemplified by Fairmont Sanur The Spa. This research used qualitative method that is constructive with literature review and management interview as the premier data source. The result of this study is finding that Fairmont Sanur The Spa needs to focus more on their promotion in terms of strategy, therefore a strategy for promotional activity is made. This research contributes to the resort spa business where they need to focus on their green movement as a whole to ensure the quality of the products and services offered. Further studies can be can be conducted to find standardization on green spa, therefore even though they have been doing all the green marketing, they do not have a certificate that can assure their green business.
\end{abstract}

Keywords : Green Marketing, Green Spa, Marketing Strategy 


\section{ABSTRAK}

Menurut para ahli, industri spa masih terus berkembang dan dapat digunakan sebagai green washing. Karena itu, penting bagi industri spa untuk juga siap menawarkan solusi yang memadai dan memimpin cara bagaimana kita dapat mencapai kesejahteraan berkelanjutan dalam melindungi dunia. Fairmont Sanur The Spa, sebagai pemenang Best Leading Spa Resort 2017/2018 oleh Bali Tourism Award menyadari meningkatnya minat pelanggan untuk 'sesuatu yang hijau' juga berdampak pada bisnis mereka. Pelanggan mereka memiliki kesadaran yang tinggi tentang lingkungan yang membuat mereka menyadari bahwa mereka mungkin harus melakukan beberapa perubahan, mulai dengan memeriksa strategi pemasaran ramah lingkungan mereka karena sampai sekarang mereka hanya fokus pada pemasaran reguler. Tujuan dari penelitian ini adalah untuk mengembangkan strategi pemasaran hijau untuk industri spa hijau yang dicontohkan oleh Fairmont Sanur The Spa. Penelitian ini menggunakan metode kualitatif yang konstruktif dengan tinjauan literatur dan wawancara manajemen sebagai sumber data utama. Hasil dari penelitian ini adalah menemukan bahwa Fairmont Sanur The Spa perlu lebih fokus pada promosi mereka dalam hal strategi, oleh karena itu strategi untuk kegiatan promosi ini pun dibuat. Penelitian ini berkontribusi pada bisnis spa resor di mana mereka perlu fokus pada gerakan hijau mereka secara keseluruhan untuk memastikan kualitas produk dan layanan yang ditawarkan. Studi lebih lanjut dapat dilakukan untuk menemukan standardisasi pada spa hijau, karena itu meskipun mereka telah melakukan semua pemasaran hijau, mereka tidak memiliki sertifikat yang dapat memastikan bisnis hijau mereka. 


\section{INTRODUCTION}

According to the expert, the spa industry is still growing and can be used as green washing. According to Green Peace, green washing can be considered as "The act of misleading consumers regarding the environmental practices of a company or the environmental benefits of a product or service". Therefore, it is important for the spa industry to also poised to offer adequate solutions and lead the way on how we can achieve sustainable well being within protecting the world (Cohen and Bodeker, 2008; Darma, 2018; Kusnadi and Darma, 2018).

Fairmont Sanur The Spa, as the winner of Best Leading Spa Resort 2017/2018 by Bali Tourism Award realize the increase interest of customer for 'something green' also impact their business. For example, customers start to ask in details about the product more often instead of just use it as it is. The customers sincere awareness about environment make them realize that they might have to run things differently from now on, starting with checking their green marketing strategy due to up until now they only focus on the regular marketing (Darma, 2019; Darma et.al., 2019).

The term "Green Marketing" has been used to describe marketing activities which attempt to reduce the negative social and environmental impacts of existing products and production systems, and which promote less damaging products and services (Peattie, 2001; Kusnadi and Darma, 2018). Green marketing includes a wide range of activities related to: product design, the manufacturing process, service delivery processes, packaging, construction and renovation of buildings, recycling, and other areas such as marketing communications (Kilbourne, 1998; Handika et.al., 2018). So basically it is a service process without damaging the environment. Despite of being the best leading spa in Bali From Fairmont Sanur The Spa's website on the picture above we can clearly see that there is no mentioning about the green marketing which actually they can use to boost their customers visit.

\section{LITERATURE REVIEW}

\section{Green Marketing}

There are several definitions of green marketing, for example as mentioned in previous chapter, according to Peattie (2011), Kusnadi and Darma (2018), green marketing is used to describe marketing activities which attempt to reduce the negative social and environmental impacts of existing products and production systems, and which promote less damaging products and services. 
Green marketing consists of a wide range of business activities which intends to satisfy customers' needs and wants, as well as diminish the negative impacts on the natural environment (Tiwari et al, 2011; Kusnadi and Darma, 2018; Darma, 2019). Green marketing also refers to an organization that puts its efforts in to promoting, pricing, and distributing products with eco-concerns (Sarkar, 2012; Kanten and Darma, 2017; Dewi and Darma, 2019; Darma, 2018).

Ottman (2006) believes in to a more complex things. He believes that a green marketing should focus more on customers' benefit. Therefore, he gathered green marketing into five rules:

1. Make the consumers be aware of and concerned about the environmental issues that your product addresses.

2. Make the consumers feel that by using your product they will make a difference.

3. Make the consumers believe your claims.

4. Make consumers believe your product will also work well as non-green alternatives.

5. Make consumers afford any premiums.

Ottman (2006) sums up green marketing by claiming that if a company follows the five rules, it can lead to product improvements that can improve marketability, strengthen overall performance and become a potential source of innovation.

\section{Green Marketing Mix}

The concept of the Green Marketing mix was first introduced by Bradley (Bradley, 2007). Bradley first introduced the concept in the late 1980s but has modified it occasionally since then. From the authors' knowledge, there is not much research done on how companies can green their marketing mix. It usually consists of product, place, price, and promotion (4P), but every company adapts its favorite marketing mix.

Suwarwan et al. (2012); Farela and Darma (2014) classify environmentally friendly products are a product who use ingredients safe for environment, energy efficient, and use material from renewable resources. The production process is done in a way to reduce the negative impact on pollution environment, starting from production, distribution channels and up to when consumed.

Agustin et al (2015); Saefulloh and Darma (2014), stated every company must decide how to make its products available to consumers. Distribution channel must pay attention to 
the convenience of consumers in obtaining products without spending a lot of energy and material burn. Some companies that produce environmentally friendly products that sell products produced through authorized distributors to maintain premium product quality.

Tiwari et al. (2011: 2), explains that prices are an important factor of the green marketing mix. Most consumers willing to pay high if there is a perception additions to product value. This value can be improve performance, function, design, attractiveness visual, or taste. Green marketing must use this fact to make temporary consideration in premium pricing.

Tiwari et al. (2011), explains that Green Promotion consists of 3 types, namely: A campaign that discusses the relationship between products / services and environmental biophysics, Campaigns that promote green lifestyles by highlighting products or services, Campaigns that provide a corporate image of environmental responsibility.

\section{Green Marketing Strategy}

According to Ginsberg and Bloom (2004); Darma (2006), green companies can choose one of the following strategies: Lean green, Defensive green, Shaded green and Extreme green.

1. Lean Green : Lean Green companies are usually uncertain about promoting their green activities and the green product attributes for fear of being held to a higher standard. The companies are afraid of not being able to live up to its claims or differentiate themselves from competitors (Ginsberg and Bloom, 2004).

2. Defensive Green : Companies recognize that green market segments are important and profitable constituencies that they cannot afford to separate from. Therefore, they use defensive green strategy in order to enhance brand image and ease the damage (Ginsberg and Bloom, 1994). On the other hand, by using this strategy companies cannot differentiate themselves from competitors on the basis of greenness. In accordance with that, efforts to promote and publicize companies' environmental initiatives are irregular and minimized, despite those initiatives being truthful sometimes (Ginsberg and Bloom, 1994).

3. Shaded Green : Shaded Green companies focus on having long-term, system wide, environmentally friendly processes that require both significant financial and non financial commitment (Ginsberg and Bloom, 2004). Shaded Green companies see green activities as an opportunity to create innovative needs-satisfying products and technologies. From this the Shaded Green companies hope to achieve a competitive advantage (Ginsberg and Bloom, 2004). 
4. Extreme Green : Companies using extreme green as a marketing strategy are embodied with holistic philosophies and values. In these companies, environmental issues and responsibility are fully incorporated into the business and product lifecycle processes (Ginsberg and Bloom, 1994). Their practices include life-cycle pricing approaches, total-quality environmental management and the manufacturing for the environment (Ginsberg and Bloom, 1994).

\section{Resort Spa}

According to International Spa Association (ISPA) spa is a place devoted to overall wellbeing through a variety of professional services that encourage the renewal of mind, body and spirit. Below are the primary type of spas and examples of the services:

1. Club Spa : a facility whose primary purpose is fitness and and which often offers a variety of professionally administered spa services on day-use basis

2. Day Spa : A spa offering a variety of professionally administered spa services on dayuse basis.

3. Destination Spa : A facility with primary purpose of guiding individual spa-goers to develop healthy habits.

4. Medical Spa : A facility that has full-time licensed health care professional on site, which is further defined as health professional who has a degree of Doctor of Medicine (M.D).

5. Mineral Spring Spa: A spa offering on an on-site source of natural mineral, thermal, or seawater used in hydrotherapy treatment.

6. Resort/Hotel Spa : A spa located in within a resort or hotel providing professionally administered spa services, fitness, and wellness components.

\section{Conseptual Framework}

Resort Spa is a spa located in within a resort or hotel providing professionally administered spa services, fitness, and wellness components. In order to develop a green marketing strategy for the spa, identification of the green marketing mix (product, price, place, and promotion) in the spa is needed to be done. Based on the spa green marketing mix, the green marketing strategy will be decided based on the category such as lean green, defensive green, shaded green, and extreme green. Once the strategy has been decided, then we can develop the most suitable green marketing strategy for the business. 


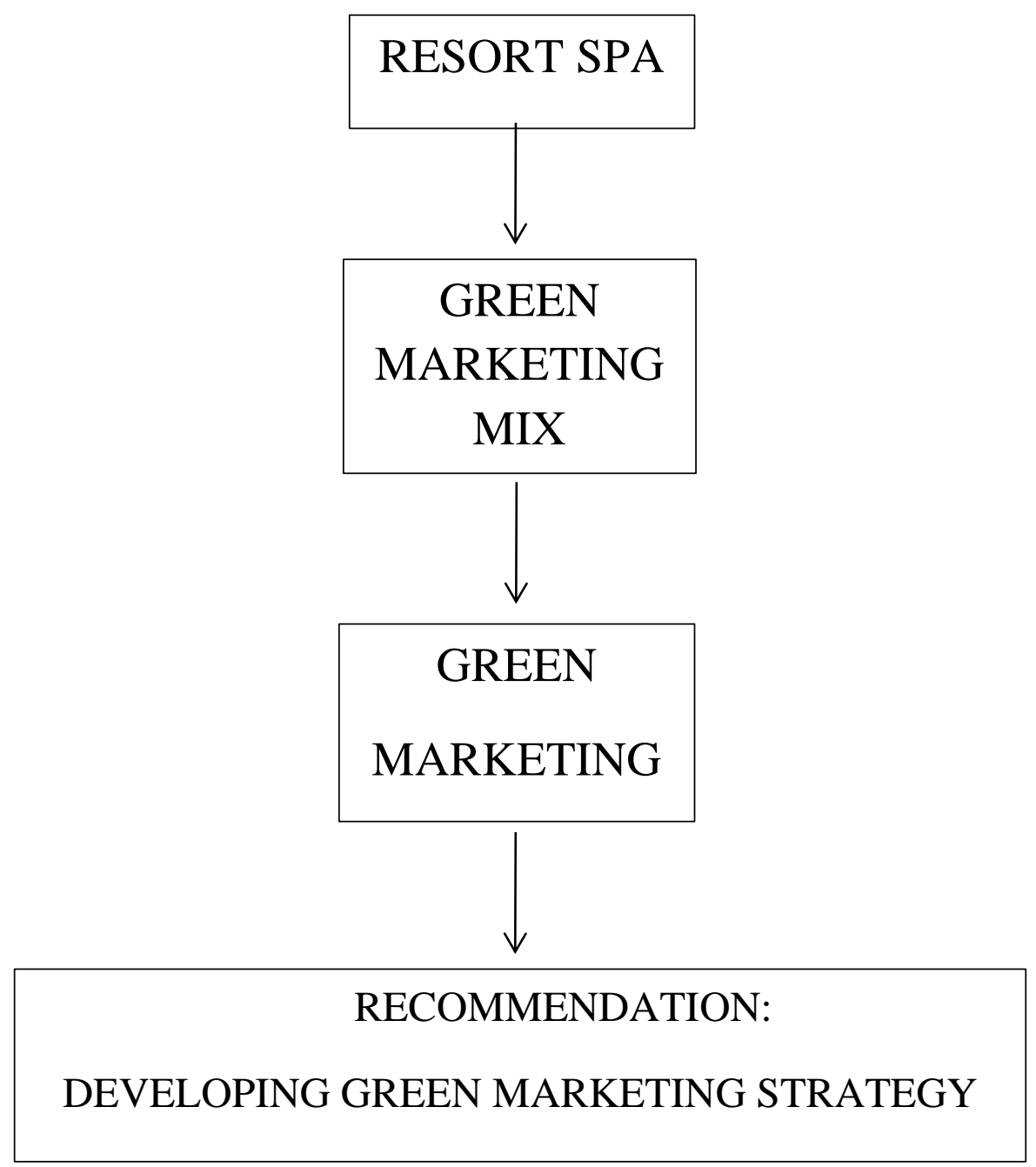

\section{RESEARCH METHOD}

This research is conducted in Fairmont Sanur The Spa On 21 February - 28 February 2019, the only five star resort in Sanur Area. The reason of choosing the said location is because The Spa Fairmont Sanur is chosen as the Best Leading Spa Resort 2017/2018 by the Bali Tourism Award and Fairmont Sanur Beach also has Green Hotel certificate from Bali Tourism Board.

The data source used are primary data and secondary data. The primary data came from the interview that the researcher did with the informants from Fairmont Sanur The Spa (Spa Manager) and customers. Interview is done using unstructured interview technique for the Spa Manager and structured interview for the customers. Secondary data came from the media that is used by Fairmont Sanur The Spa as marketing media. 


\section{RESEARCH FINDINGS AND DISCUSSION}

Based on the the research process conducted by researchers in a way of interviewing several informants from various research settings, therefore, the research findings are as follow:

1. Fairmont Sanur The Spa offers type of products and services that are cater to the resort guest in order to give them the best staying experience.

2. Fairmont Sanur The Spa is concerned not only for the customers but also for the environment as well, it can be seen by the way they choose their products.

3. Despite of the difficulties for the customers to find their product elsewhere but it's understandable since The Spa needs to maintain their exclusivity and their quality by limiting the access and using only a licensed distributor or supplier for their products.

4. Fairmont Sanur The Spa always explains to the customers about their green product and their contribution to the environment. However all of these are done verbally to the customers while they are in The Spa. They do not advertise themselves well regarding this crucial matter, not even on their own Home website.

Based on the data that the author has collected, we can categorized The Spa chose the Defensive Green category where they take their green market segment into consideration and tries the best to accommodate their needs, however in term of promotion, the efforts to promote and publicize companies' environmental initiatives are irregular and minimized. Should they want to improve themselves, Shaded Green strategy is what is best for them at the moment due to certain reasons:

a. Judging by how they manage their selection of products, the way they contribute to the society, Fairmont Sanur The Spa actually has fulfilled having long-term, system wide, environmentally friendly processes that require both significant financial and non financial commitment.

b. Fairmont The Spa actually has quite number of green activities that can be used for their competitive advantage. For example : Fairmont Sanur The Spa actually partnered with Bali Role Foundation, a non profit organization, that is focusing on waste management and local business. 


\section{CLOSING}

The aim of research is to find out the most suitable and realistic green marketing strategy for resort spa business especially for Fairmont Sanur The Spa. Based on the data and discussion, defensive green strategy is where the company is now, means the Spa is doing excellent job in terms of green product, green pricing, and distribution. However, they are still lack in the most crucial part which is the green promotion. Therefore, in order to bring themselves more forward, choosing shaded green strategy will be the best for their business to achieve a competitive advantage.

Based on the research findings, there are several research findings expected to be practical contribution for resort spa business, such as: Product selection must be done in details, maintaining quality of product and service, affiliating and supporting green movement or activity so customers can be assure that their money is for a good cause, and doing promotional activity regarding the resort spa itself and focusing on the green marketing. As for the policy, There should be standardized regulation for green spa category, therefore customers can be assure and no need to worry regarding their choice of place.

Researchers are aware of the limitations that we have, that we cannot examine all the problems that occur in the resort spa industry, So the researchers hope that with this recommendation, we can provide guidance for future research related to problems or industries related to this research. 


\section{REFERENCE}

Agustin, R.D., S. Kumadji, E. Yulianto. (2015). Pengaruh Green Marketing Terhadap Minat Beli serta Dampaknya pada Keputusan Pembelian, Jurnal Administrasi Bisnis (JAB), 22 (2).

Bradley, N. (2007). The Green Marketing Mix. Retrieved September 20, 2018, from http://www.wmin.ac.uk/marketingresearch/Marketing/greenmix.htm

Cohen, M., \& Bodeker, G. (2008). Understanding the global spa industry. Spa Management. Burlington: Butterworth-Heinemann.

Darma, G.S. (2019). Kacamata Media, Kesuksesan Bersyarat. Indonesia: Pustaka Larasan Press.

Darma, G.S. (1999). Information Technology and Organisational Performance: A Study of the Hospitality Industry, Southern Cross University, Lismore New South Wales Australia.

Dewi, M.V.K., and Darma, G.S. (2019). The Role of Marketing \& Competitive Intelligence In Industrial Revolution 4.0, Jurnal Manajemen \& Bisnis, 16 (1): 1-12.

Darma, G.S. (2018). Seuntai Pesan, Menjawab Zaman. Indonesia: Pustaka Larasan Press.

Darma, G.S. (2006). Mobile Marketing: Sebuah Strategi Keunggulan Bersaing Online. Denpasar: Undiknas Press.

Farela, D., and Darma, G.S. (2014). Celebrity Endorser, Daya Tarik Iklan, Brand Awareness dan Brand Attitude, Jurnal Manajemen \& Bisnis, 11 (1): 35-47.

Ginsberg, J. M., \& Bloom, P. N. (2004). Choosing the right green marketing strategy, MIT Sloan Management Review, 46.

Handika, M.R., Maradona, A.F., and Darma, G.S. (2018). Strategi Pemasaran Bisnis Kuliner Menggunakan Influencer Melalui Media Sosial, Jurnal Manajemen \& Bisnis, 15 (2): 188-199.

Kanten, I.K., and Darma, G.S. (2017). Consumer Behaviour, Marketing Strategy, Customer Satisfaction, and Business Performance, Jurnal Manajemen \& Bisnis, 14 (2): 143-165.

Kilbourne, W.E. (1998). Green marketing : A Theoretical Perspective, Journal of Marketing Management.

Kusnadi, D.S., and Darma, G.S. (2018). Menakar Implementasi Green Marketing Pada Usaha Kecil Menengah, Jurnal Manajemen \& Bisnis, 15 (1): 1-18.

Ottman, J. A., Stafford, E. R., \& Hartman, C. L. (2006). Avoiding green marketing myopia. Environment, 48 (5): 22-36, 2. Retrieved from 
http://ezproxy.snhu.edu/login?url=http://search.proquest.com/docview/224016352?acco untid $=3783$

Ottman, J. A. (2011). The new rules of green marketing: Strategies, Tools, and Inspiration for Sustainable Branding. Retrieved from http://www.greenleafpublishing.com/content/pdfs/NRoGM_ch1_2.pd

Peattie, K. (2001). Towards Sustainability: The Third Age of Green Marketing. Marketing Review.

Saefulloh, D.A., and Darma, G.S. (2014). Strategi Marketing Wisata Wedding Sebagai Destinasi Alternatif, Jurnal Manajemen \& Bisnis, 11 (1): 17-34.

Sarkar, A. N. (2012). Green branding and eco-innovations for evolving a sustainable green marketing strategy, Asia-Pacific Journal of Management Research and Innovation, 8 (1): $39-58$.

Sumarwan, U., A.G, Prihartono, A.W Sumarlin, D.A. Mamahit, E. Purnomo Hadi, J. Hasan, M. Ahmady, R. Wulandari, T. Haryono. (2012). Riset Pemasaran dan Konsumen, Seri 2. Bogor: PT Penerbit IPB Press.

Tiwari, S., Tripathi, D. M., Srivastava, U., \& Yadav, P. K. (2011). Green marketing - emerging dimensions, Journal of Business Excellence, 2 (1): 18-23. Retrieved from http://ezproxy.snhu.edu/login?url=http://search.proquest.com/docview/1010336807?a ccountid $=3783$. 